\title{
Developing English Textbooks Oriented to Higher Order Thinking Skills for Students of Vocational High Schools in Yogyakarta
}

\author{
Margana \\ Faculty of Languages and Arts, Yogyakarta State University, Yogyakarta, Indonesia \\ Agus Widyantoro \\ Faculty of Languages and Arts, Yogyakarta State University, Yogyakarta, Indonesia
}

\begin{abstract}
This article is part of research and development under the issue of developing English textbooks oriented to the enhancement of higher order thinking skills (HOTS) for students of vocational high schools (VHSs) in Yogyakarta. This relies on the evidence that the existing textbooks for secondary school levels put an emphasis on memorizing and comprehending which highlight to identify linguistic features of the target language (micro-language skills). This leads to creating the failure of acquiring English language proficiency on the part of students of secondary school levels including students of VHSs. To obtain the objective, there were 14 English teachers and 320 students of vocational high schools from three regencies, namely Sleman, Yogyakarta city, and Bantul voluntarily involved. Three techniques: questionnaire distributions, interviews, and documentation were administered to get data. Then, the gathered data were analyzed using a descriptive qualitative method. In reference to data analysis, four findings are documented as explored in this part of this article. In summary, the development of the English textbooks oriented to HOTS is positively responded by the respondents as the English textbook triggers students of VHSs to establish their higher order thinking skills which lead to students' creativity and self-regulated learning practices.
\end{abstract}

Index Terms — higher order thinking skills, lower order thinking skills, English textbook

\section{INTRODUCTION}

In the process of teaching and learning, the availability of textbooks is one of the essential components that must exist because textbooks serve as a guide for students and their teachers of any level of education to be actively engaged in classroom practices. This is in line with Iqbal (2013) who urges that existence of the textbooks could facilitate students to maximally achieve the targeted learning objectives. Added to this, textbooks serve as the core of educational practices, confer students with "a rich array of new and potentially interesting facts, and open the door to a world of fantastic experience" (Chambliss \& Calfee, 1998, p.7). This suggests that textbooks play an important role to succeed for the teaching and learning practices. In relation to this statement, Kitao \& Kitao (1997) articulate that textbooks are of great importance in the process of teaching and learning as they serve as the center of instruction and describe what goes on in the classroom practices in order that the teaching and learning activities become efficient, effective, and meaningful.

Realizing how important the textbooks are, the Indonesian government via the ministry of education and culture assigns the centre for curriculum and textbook development to write a great number of textbooks for any subjects used in any level of education (elementary and secondary school levels) including English textbooks. Those textbooks are nationally mandated to be used by the schools in line with the implementation of the new curriculum (the 2013 one). This suggests that all secondary high schools (junior, senior, and vocational high schools) are obligated to use the textbooks which are developed by the centre for curriculum and textbook development serving as the main textbooks in the process of English language teaching and learning.

In the level of secondary schools, SVHSs (senior high and vocational high schools) in particular, the centre for curriculum and textbook development designed six sets of English textbooks. Every grade has two sets of English textbooks on the basis of semester. They are labeled with English textbooks for students of Grade X semester 1 and of Grade X semester 2. The same labels are applied for Grade XI and XII. These English textbooks are developed in reference to the core competence and basic competence which do not differentiate the types of the schools. In other words, those six sets of the English textbooks are nationally used by students of SVHSs. Those English textbooks are also used for students of religious-based senior high and vocational high schools including Christian, Catholic, and Islamic senior and vocational high schools in Indonesia which run the 2013 curriculum.

As a matter of fact, students of SVHSs are different in nature in terms of orientation and expectation. The orientation of the English textbooks for students of SHSs is designed by putting an emphasis on English for academic purposes. On the other hand, students of VHSs should be oriented to the development of English for specific purposes on the grounds 
that students of VHSs are projected to learn different fields according to their study programs. For example, when they take a business and management study program, the English materials should be related to their fields, namely business and management development instead of general English. In terms of expectation, students of SHSs are projected to proceed their study in a high level such as universities or colleges. On other hand, students of VHSs are projected to be skillful workers in reference to their fields. This suggests that the English textbooks used by students of SVHSs should be different in nature.

With regard to the above statements, students of SHSs should be oriented to English for academic purposes which give an emphasis on the development of the macro-language skills such as listening, speaking, reading, and writing in which reading becomes the center of English development. Added to this, students of SHSs are also driven to deeply understand the nature of micro-language skills such as grammar, structure, vocabulary, pronunciation, and the like in reference to English for academic purposes (EAPs) with regard to their concentrations offered in those schools which include natural sciences, social studies, and language studies. On the other hand, students of VHSs deal with English for specific purposes (ESPs) which also develop macro-language skills as above mentioned, articulating on speaking in order to facilitate them to make use of English in some communicative events relevant to their workplaces. The microlanguage skills as above mentioned are also presented for students of VHSs which are embedded in the macro-language skills which articulate on how they are used in discourse of workplaces.

In reference to ESPs, according to Richards and Schmidt (2010), ESP is defined as 'a language course or program of pedagogical practices which consist of the content areas and objectives of the course with regard to the fixed specific needs of a particular group of learners" ( $p, 198)$. This relies on the theory that different groups of learners should have specific needs according to their backgrounds. Therefore, the English textbooks used for students of VHSs should be different from those for students of SHSs. Further, Jordan (1997) cited in Tsou (2009) articulates that ESP textbooks should deal with subject-specific materials which are designed according to targeted topics.

More importantly, the English textbooks designed for students of SVHSs should be oriented to the development of students' thinking skills on the grounds that students are accustomed to handling challenging tasks which trigger them to be fully engaged in the process of English language teaching and learning enabling them to lateralize the target language (English). In relation to this statement, Putcha (2012) strongly urges that when second language learners (SLLs) are accustomed to systematically employing their critical thinking skills, they get positive experiences of learning practices and could encounter any demanding tasks which can in turn establish their own self-confidence to learn English better. In the same spirits, a great number of experts highly recommend that LOTS and HOTS should be embedded in the process of English language teaching and learning including the development of English textbooks (Huberty \& Davis, 1998; Cotton, 1997; Young, 1997; Ennis, 1993; Carrol, 1989). This relies on theories that LOTS and HOTS are of great importance for SLLs to establish their own regulated learning strategies (Huberty \& Davis, 1998). This is supported by the educators who strongly claim that it is important to promote higher-order thinking skills in the process of English language teaching and learning (Chamot, 1995; Tarvin \& Al-Arishi, 1991). This is supported by empirical evidence which reveals the strengths of teaching critical thinking skills in the process of English language teaching and learning at any level of education (Chapple \& Curtis, 2000; Davidson, 1994, 1995, 1998).

However, the analysis of the English textbooks used for students of SVHSs conducted by Margana (2015) reveals that the English textbooks used for SVHS students in Indonesia are developed under the basis of LOTS ignoring HOTS on the grounds that the tasks of the English textbooks are dominated by knowing and memorizing the language systems such as grammar or structure, vocabulary, pronunciation, and the like. Added to this, the exercises for the development of receptive macro-language skills such as listening and reading are only oriented to testing practices which articulate the factual questions instead of analytical questions.

The development of speaking as one of the productive language skills somehow as performed in the English textbooks focuses on the memorization of the dialog with the application of audio-lingual methods which mostly articulate the use of a drilling technique. This also happens in the development of writing skills which are oriented to the product approach putting an emphasis on rearranging sentences. This evidence directly or indirectly determines the failure of the acquisition of the target language (English) on the grounds that students are only driven to deal with systemic knowledge which is oriented to understanding the outer layer of the language system as stated by Hedge (2008).

Furthermore, the English textbooks are developed without implementing the needs assessment or analysis. Rarely do the writers of English textbooks deal with needs assessment, namely a process of gathering and analyzing data from the targeted learners. In other words, the English textbooks are not developed under the issue of learning needs and target needs. Learning needs refer to the nature or the essence of learning while target needs are concerned with the objectives of learning both of which are gained through needs assessment from the students. These two issues are neglected in developing the English textbooks nationally used in Indonesia as the writers only refer to the core and basic competence which exist in the national curriculum. Furthermore, the English textbooks are only validated by some experts without conducting experimental judgment.

In reference to the above issues, the development of the English textbooks for students of VHSs which highlight on the establishment of HOTS is urgently required. This suggests that the aspects of HOTS such as skills of analyzing, evaluating, and creating should be manifested in the development of the English textbooks used for students of VHSs. 
Also, the tasks or activities used in the English textbooks must activate those three types of thinking skills on the grounds that those skills are believed to maximally facilitate students of VHSs to acquire English.

\section{LITERATURE REVIEW}

Nowadays, there have been a growing number of English textbooks developed by some prominent authors as English textbooks confer a great number of benefits for second language learners (SLLs) and second language teachers (SLTs). For example, Hutchinson and Torres (1994) confer four advantages of textbooks. They are (1) serving as a vehicle for teachers and learners in the process of English language teaching and learning, (2) providing support and relief from the psychological burden on the parts of SLLs, (3) performing a complete picture of the change of learners' behavior through learning and teaching practices, and (4) providing SLTs with the psychological support because of having less experience in English language teaching and learning. In the same spirit, Cunningsworth (1995) proposes six roles of English textbooks which include (1) serving as a syllabus in reference to pre-determined learning objectives, (2) conferring an effective resource for students' self-directed learning, (3) offering an effective medium for presentation of new material, (4) providing students with a source of ideas and activities, (e) serving as a reference source for students and teachers, and (5) equipping support for less experienced teachers who need to gain confidence.

In reference to the above advantages, Richards (2001) documents seven advantages of the existence of the English textbooks. They include (1) providing a description of the structure and the syllabus of the program, (2) conferring standardized instruction, (3) assuring the quality of the learning process, (4) offering a variety of learning resources, (5) facilitating SLLs and SLTs to be efficient in the process of English language teaching and learning, (6) conferring effective language model and input, (7) serving as a medium of initial teacher training, and providing SLLs and SLTs with a visually appealing model. This suggests that English textbooks should be well developed in order to facilitate SLLs and SLTs to effectively and efficiently run the process of English language teaching and learning at any levels of education including secondary school levels.

With regard to the above advantages, it is evident that English textbooks confer some convincing positive impacts on the success for acquiring the target language on the grounds that English textbooks serve as the resource of learners and teachers to conduct the process of English language teaching and learning which meets the curriculum and learners' characteristics. This suggests that English textbooks should be well developed, otherwise they only become obsolete and useless documents. In relation to this statement, many experts propose some criteria of English textbooks. Cunningsworth (1995), for example, proposes four criteria which include (1) accommodating learners' needs, (2) equipping students to use language effectively, (3) facilitating learners to the process of learning, and (4) having a clear role as learning support. In reference to these criteria, needs analysis should be conducted in order to generate effective and efficient English textbooks otherwise the English textbooks only serve as formal documents which could not facilitate SLLs to maximally acquire the target language.

In line with the above criteria, Richards \& Rodgers cited in Mukundan \& Ahour (2010) state that the development of English textbooks should take into account for learners' roles, teachers' roles, instructional materials, and targeted syllabus. In addition, English textbooks should also accommodate learners' and teachers' interests and needs and the context of learning (Byrd, 2001; Bell \& Gower, 1998; Sheldon, 1988). Cunningsworth \& Kusel (1991) add some issues of good English textbooks which include aims, layout, methodology, and organization. More specifically, the English textbooks have to consider some issues such as language forms which include macro-language skills (listening, speaking, reading, and writing) and micro-language skills (grammar, vocabulary, etc.), and language functions which are presented in the textbook depending on the present socio-cultural setting (Nejmeh, 2011; Mayfield, 2001; Zabawa, 2001; Ur, 1996; Cunningsworth, 1995; Harmer, 1991).

Of the criteria above, a great number of experts tend to ignore the issue of the development of thinking skills as one of the criteria of good English textbooks. The enhancement of thinking skills should be articulated in the development of English textbooks because the development of thinking skills as manifested in English textbooks facilitate SLLs to independently learn the target language and to establish students' creativity and autonomous learning practices so that they could acquire the target language maximally. In line with this statement, this paper articulates the development of learners' thinking skills as manifested in the English textbooks which are designed for students of VHSs. This relies on the theory that the development of learners' thinking skills could facilitate them to maximally acquire the target language (Ezici, 2006); Facione, 1998; Beyer, 1988, 1995, 1997; Cramp et al,. 1988). Through the development of thinking skills, SLLs deal with some activities such as (1) breaking down complex material into parts, (2) detecting relationships, (3) combining new and familiar information creatively within limits set by the context, and (4) combining and using all previous levels in evaluating or making judgments (King, Goodson, \& Rohani, 2007). In the same spirit, Jacobs (1994) advocates that the ways of students' thinking skills play an important role in making choices of learning activities and interpreting the learning tasks according to the relevant situations. This implies that the development of English textbooks does not only meet learners' needs and interests but also drive SLLs to develop their thinking skills through the tasks or activities which exist in English textbooks.

In regard to the development of thinking skills, many experts classify them into two types, namely lower order thinking skills and higher order thinking skills (Anderson et al., 2001; Pohl, 2000). LOTS are concerned with types of thinking skills which do not require high level of thinking skills. In this level, SLLs only deal with receptive tasks, 
namely deconstructing the texts with the use of memorizing, comprehending, and analyzing the tasks. HOTS deal with the application of the high level of thinking which includes synthesizing, evaluating, and creating. Those sub-three thinking skills are concerned with handling the productive tasks.

With regard to those types of thinking skills, a great number of experts come to agreement that both should be embedded in the process of English language teaching and learning including in the development of English textbooks (Cotton, 1997; Huberty \& Davis, 1998; King, 1997; Young, 1997; Ennis, 1993; Carrol, 1989) on the grounds that LOTS and HOTS are of great importance for SLLs to establish their own learning strategies so that they could regulate their own learning practices. However, of the two types of thinking skills, HOTS should be emphasized. Renner (1997) as citied by Liaw (2007) strongly articulates that use of critical thinking skills in the English textbooks could enhance SLLs' critical thinking skills which in turn enable them to maximally acquire their English proficiency as thinking skill development and language attainment are interwoven in nature. Added to this, critical thinking skills are recognized as a determinant or significant capability to maximally acquire in academic language (Connolly, 2000; Davidson, 1998; Davidson \& Dunham, 1997). This clearly implies that the development of thinking skills should be the concern of English textbook writers.

\section{Methodology}

This study is categorized as research and development which focus on the development of the English textbook for students of VHSs articulating the high order thinking skills as manifested in the tasks. To obtain the objective, the researchers voluntarily invited 14 English teachers and 320 students from six VHSs from three regencies, namely Sleman, Yogyakarta city, and Bantul as the subjects of this study. To select the respondents, the researcher utilized a random sampling technique. This was conducted by writing the targeted VHSs which offered business and management program in a piece of paper for each, to select the schools. After that, the paper was rolled and put in the box. Then, the researchers took six papers to be included in research according to the label which was written in the paper.

Three techniques: questionnaire distributions, interviews, and documentation were administered to gather data which articulate the needs assessment. To do so, the instruments: questionnaire, interview guideline, and list of document evaluation were used to take data. Questionnaire was designed to reveal the learning needs and target needs as the basis of the development of the English texts. This questionnaire was distributed to students of VHSs. The interview guideline was designed to get data from the English teachers of VHSs. In the interview, the English teachers were questioned under the issue of the English textbooks used both at SVHSs and the issue of development of high order thinking skills in English textbooks. The gathered data were then analyzed with the use of descriptive qualitative method.

\section{FINDINGS AND DiscUSSION}

In reference to the needs analysis, the following presents some findings. First, it is evident that all respondents (320 students and 14 English teachers of VHSs in three regencies) agree to the issue of developing the English textbooks oriented HOTS as this triggers students to establish their critical thinking skills which lead to students' creativity and autonomous learning. Most of English teachers also state that the articulation of HOTS in the English textbook could drive students to critically analyze the use of language according to the social contexts. This relies on the fact that so far the existing English textbooks designed for VHSs have only dealt with the application of LOTS, namely memorizing the language form such as sentence patterns, vocabulary, pronunciation, and the like. Such voices were also supported by 315 out 320 students' responses which were obtained through questionnaire claiming that the existing English textbooks used in the process of the English teaching and learning at VHSs articulate on memorization of the language forms such as vocabulary, pronunciation, and grammar as shown in the following data.

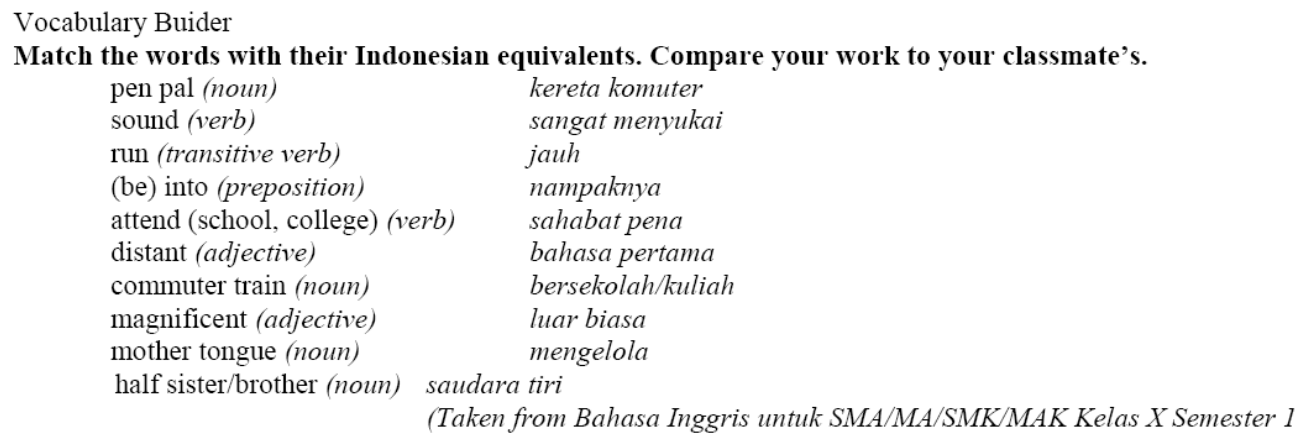

In reference to the above data, it is evident that students are driven to deal with isolated vocabulary items. This task deals with memorizing the equivalent meanings of the vocabulary items with the use of translation method. This task 
applies LOTS development, namely memorizing and understanding the vocabulary items in English and Indonesian language. Such evidence also happens in pronunciation as shown in the following data.

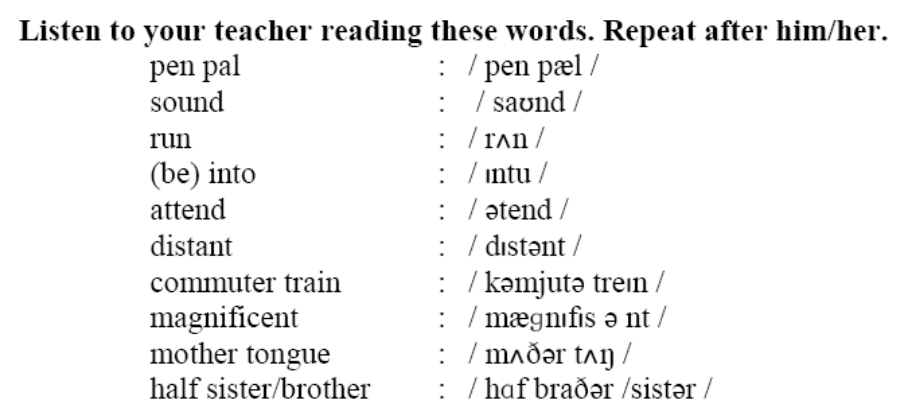

(Taken from Bahasa Inggris untuk SMA/MA/SMK/MAK Kelas X Semester 1

The data above perform that students are driven to only memorize how to pronounce the lexical items by using a drilling technique. This is also categorized as LOTS development as students only deal with repeating their English teachers in pronouncing words or phrases. The same case also happens in grammar presentation as shown in the following data.

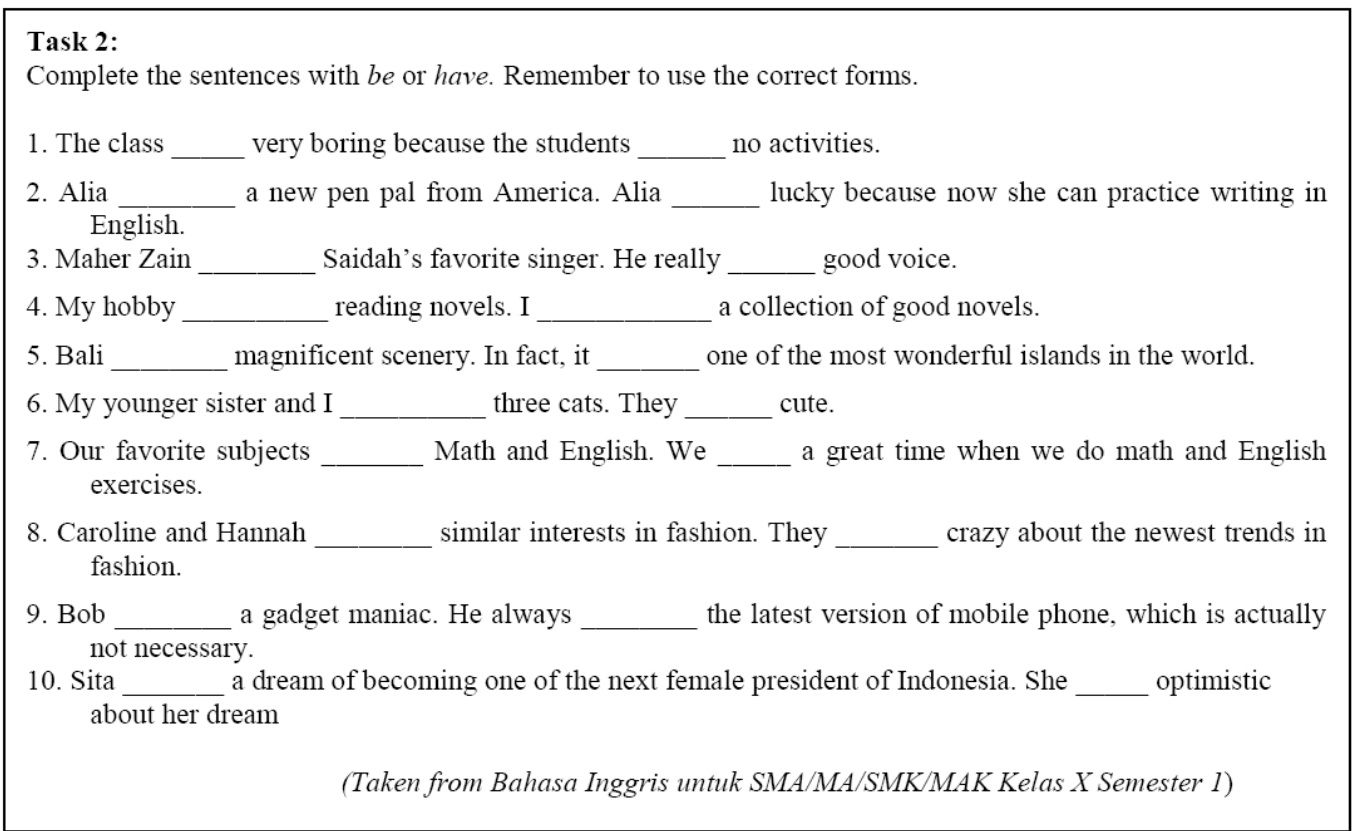

The above data clearly perform that students are driven to only apply lower order thinking skills as the students are engaged in selecting the form of is, am, are or the form of have or has to complete sentences. This is also a part of LOTS development as students only memorize the use of be and have and apply them in the incomplete sentences. As a matter of fact, the presentation of micro-language skills such as grammar/structure, vocabulary, and pronunciation in the English textbooks for students of VHSs could be done inductively. This means that those micro-language skills are embedded in both spoken and written texts. Students are then asked to deconstruct the text with the use of bottom-up processing which articulates the analysis of language forms such as grammar/structure, vocabulary, and pronunciation. In this case, students could apply high order thinking skills in analyzing the texts depending on the language focus which is accentuated. By the application of the HOTS, students could generate the rule of grammar or structure based on the text, the meanings of the vocabulary items based on the contexts, and the way of pronouncing words in the text. This leads them to establishing the strategy of deconstructing the texts which drives them to learn the materials autonomously.

In reference to the questionnaire about the development of HOTS in the existing English textbooks, 14 English teachers voiced that the existing book articulated LOTS development in the presentation of reading skills as part of macro-language skills as shown in the following data. 
Text 1: An email from Hannah

Hello, Alia! Let me introduce myself. My name is Hannah.

I know your name from my friend, Caroline. She told me that you sent her an email telling her that you would like to have more pen pals from the US. I'd really like to be your E-pal. You sound really cool!

I guess I'd better tell you something about myself first. I'm 16 years old and I attend Thomas Edison High School here in Minneapolis, Minnesota, USA. I have two brothers and two half sisters and I'm the middle child. My father died a few years ago so my mother runs the house and the family business. My father was a barista.

I have lots of hobbies. I like music - mostly classical music and folk music - but I don't play an instrument. I like sports, especially tennis and basketball. At school I'm in the basketball team and I spend most of my extra-curricular time playing basket ball. I'm into animals very much. My sister and I have three dogs, a rabbit and an iguana. They need lots of attention as you can imagine. At school, I have many Hmong friends who were not fully fluent in English. Their family moved here from Asia. I enjoy talking to them about our different cultures. My favorite subjects at school are art and geography. I think I'd like to become a park ranger when I graduate, perhaps work for the National Parks Service.

I haven't got much interest in fashion, although we have 'Mall of America,' the biggest mall in Minnesota. We can reach the mall very easily. A commuter train runs every 15 minutes, buses also come from different directions. We can also drive to the mall. It's much faster than going there by train or by bus.

I don't like reading but I love drawing and painting.

How about you? Please drop me a line, Alia! Can’t wait to hear from you!

Hannah.

Answer the following questions briefly.

1. How does Hannah contact Alia? Is there anybody introducing Hannah to Alia?

2. Does Hannah want to be Alia's friend?

3. Where does Hannah study?

4. Tell me about Hannah's family!

5. What are Hannah's hobbies?

6. Does she like animals? What animals does she have?

7. What do Hannah and her among friends love to do?

8. What profession would she like to have after graduating from her school?

9. She isn't interested in fashion. Why?

(Taken from Bahasa Inggris untuk SMA/MA/SMK/MAK Kelas X Semester 1)

With regard to the data above, the comprehension questions of reading skills are also oriented to the development of LOTS as most of questions are dominated by factual questions. For example, Q1 to Q8 only deal with factual questions which require understanding and memorizing the text. In other words, those questions do not drive students to analyze and evaluate the text. Only one question, namely Q9 is categorized as a HOTS question, which analyzes the reason for being interested in fashion. The same evidence is presented below. 
Read the following text, and then answer the following questions.

\section{MY BEST FRIEND}

I have a lot of friends in my school, but Dinda has been my best friend since junior high school. We don't study in the same class, but we meet at school everyday during recess and after school. I first met her at junior high school orientation and we've been friends ever since.

Dinda is good-looking. She's not too tall, with fair skin and wavy black hair that she often puts in a ponytail. At school, she wears the uniform. Other than that, she likes to wear jeans, casual t-shirts and sneakers. Her favourite t-shirts are those in bright colors like pink, light green and orange. She is always cheerful. She is also very friendly and likes to make friends with anyone. Like many other girls, she is also talkative. She likes to share her thoughts and feelings to her friends. I think that's why many friends enjoy her company. However, she can be a bit childish sometimes. For example, when she doesn't get what she wants, she acts like a child and stamps her feet.

Dinda loves drawing, especially the manga characters. She always has a sketchbook with her everywhere she goes. She would spend some time to draw the manga characters from her imagination. Her sketches are amazingly great. I'm really glad to have a best friend like Dinda.

\section{Comprehension Questions}

1. Who is being described in the text?

2 . How long have the writer and Dinda been friends?

3. What does Dinda look like?

4. What are her favourite clothes?

5 . What kind of $t$-shirts does she like?

6. Describe Dinda's personality briefly.

7. Why do many friends enjoy Dinda's company?

8. What is Dinda's bad habit?

9. What is Dinda's hobby?

10. How does the writer feel about Dinda?

(Taken from Bahasa Inggris untuk SMA/MA/SMK/MAK Kelas X Semester 1)

The above text shows that the writers articulate on developing LOTS as 9 out 10 reading comprehension questions are concerned with the application of memorizing and understanding factual information from the provided text. For example, the answers for Q1 to Q10 except Q7 could be explicitly answered from the text as those are categorized as factual questions. Only Q7 is categorized as a HOTS question because it requires reasoning thinking skills. The same case also happens in speaking task as presented below. 


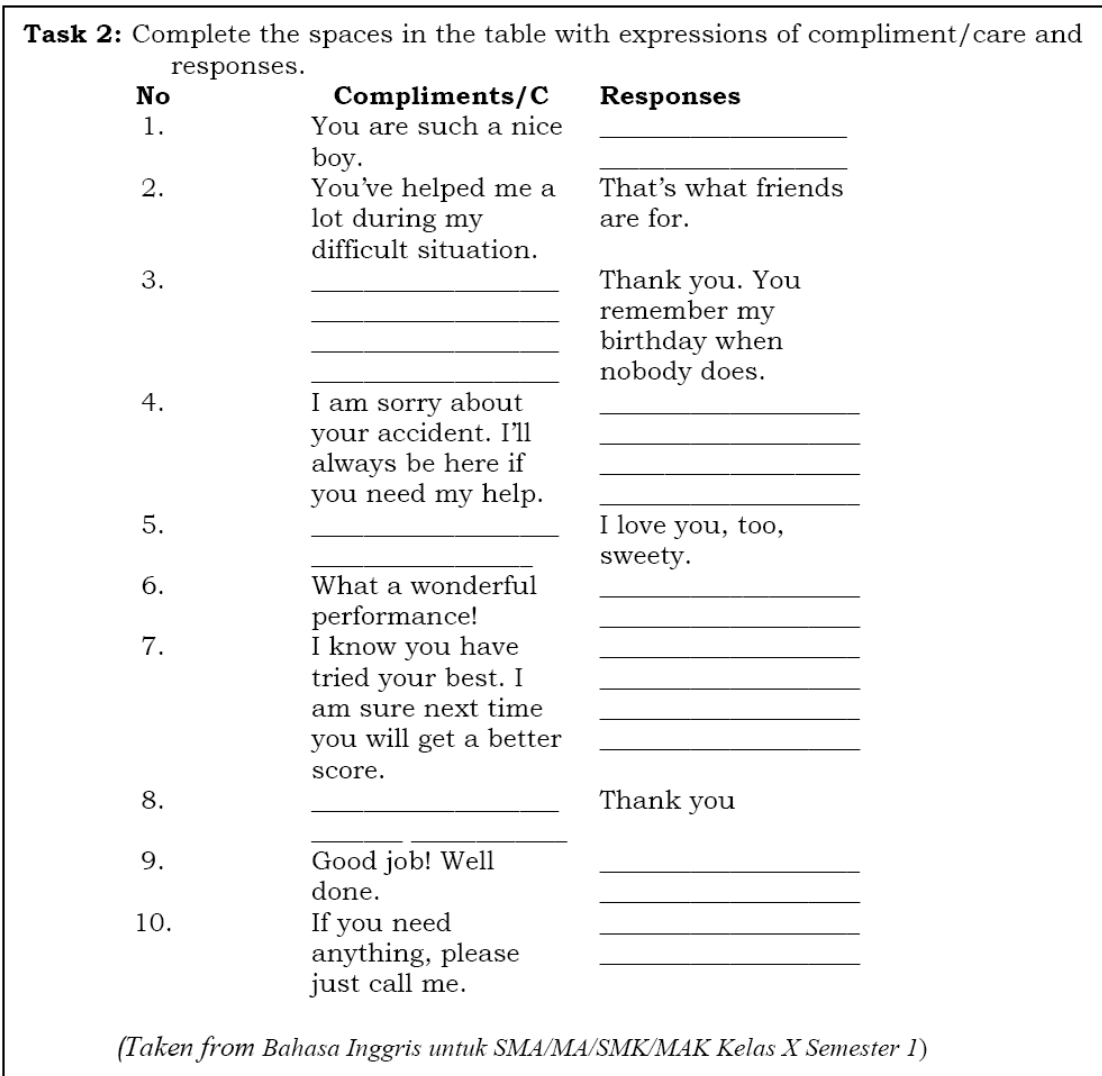

The above data show that the task above requires students to only apply LOTS as they deal with memorizing and comparing the expressions of compliment/care and responses as the focus of the task. This evidence inspires English teacher cohorts to propose the articulation of HOTS in developing the English text for students of VHSs. This statement is supported by student cohorts who stated that the English textbook for VHS students should highlight on the HOTS development rather than LOTS one. Such development should be also applied in the presentation of listening and writing lesson.

Second, with the utilization of questionnaire, both cohorts come to the agreement that the English textbook used for students of VHSs should be different from students of SHSs on the grounds that students of VHSs are driven to learn English for specific purposes which are closely related to their backgrounds, namely business management. In other words, the content of the English textbook should be relevant to the development of macro-language skills (listening, speaking, reading, and writing) and micro-language skills (grammar/structure, vocabulary, pronunciation, and the like) under the issue of business management. Of the four macro-language skills, 300 out of 320 student cohorts put an emphasis on speaking, 10 students articulated reading pratices, 6 students focused on writing, and 4 students dealt with listening practices. The following presents the pie chart to show the preferences of students.

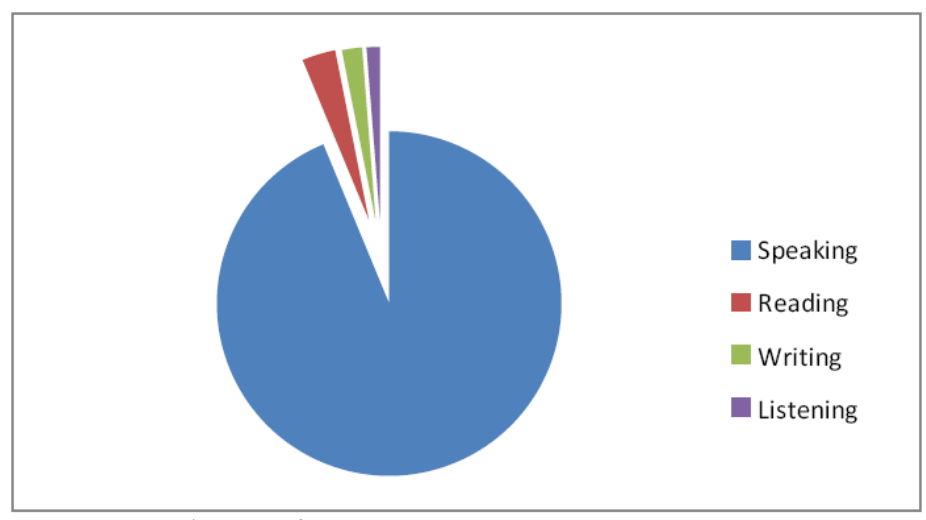

Figure 1. Students' preferences on macro-language skills in English textbook

The preference on speaking is also supported by English teachers of VHSs claiming that the English textbooks should encompass four macro-language skills above, but the development of speaking skills should be prioritized without disregarding the other three macro-language skills (reading, writing, and listening). In terms of the micro- 
language skills, both cohorts agree that the micro-language skills should be integrated into macro-language skills in both spoken and written texts. They also state that the micro-language skills should be based on the contexts not in isolation.

Third, in reference to the English textbook used for students of VHSs, it is found that a great number of texts are not contextual. This inspires the student and English teacher cohorts to state that the English textbook for VHSs should be contextual in the sense that the texts should be related to the social contexts which are derived from the inner, outer, or expanding circle English speaking countries in order to easily understand how the language is used according to the real contexts. In addition, 305 out of 320 students agree that the English textbooks should consist of authentic texts derived from workplaces which are relevant to business and management. The following data show the example of decontextualization of the texts that exist in the English textbook used for students of VHSs.

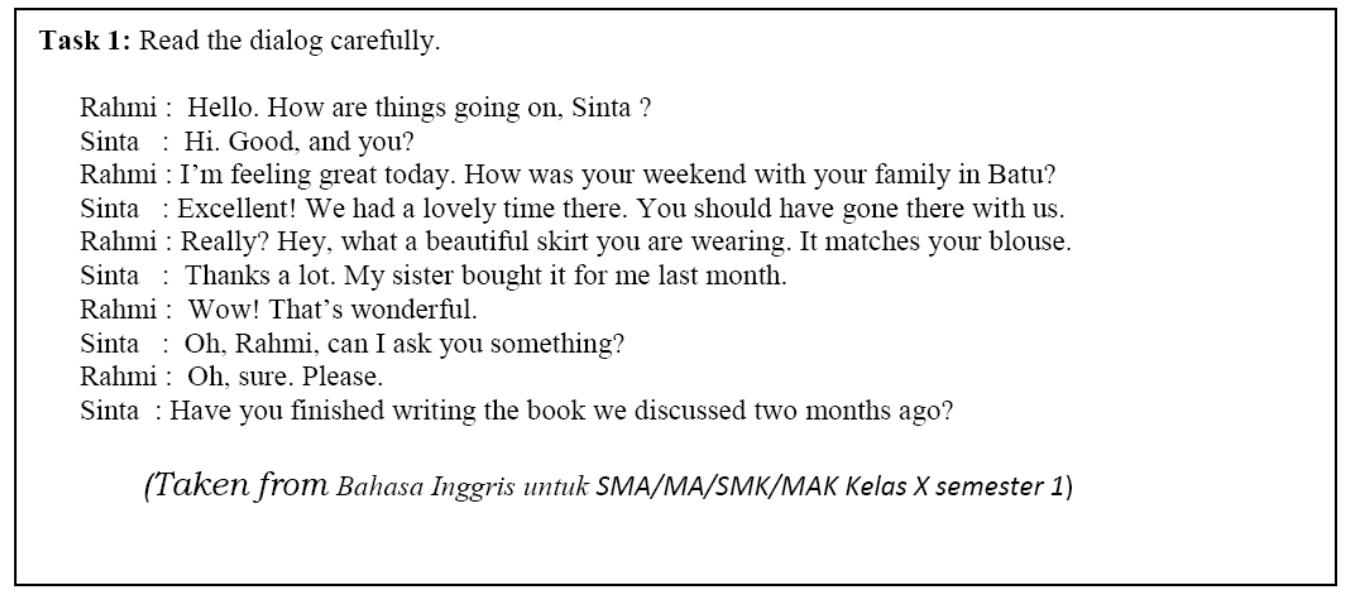

With regard to the above text, the writers decontextualize the text as the dialog takes participants of Indonesian students who are talking about spending weekend in Batu (one of the tourism spots in Malang, Indonesia) and a beautiful skirt. It is not common for Rahmi and Shinta to use English as a means of communication practices. To contextualize the above text, the writers could give the context of a situation by changing the participants of the dialog, for example, Anne (English name) and Shinta (Indonesian name) or by giving a context that Sinta and Rahmi are students of VHSs who are now practicing English.

Fourth, with the use of questionnaire, 305 out 320 students propose to select authentic texts which are derived from the workplaces under the issues of business management such as advertisements, business letters, supply and demand, and the like which can be taken from internet, newspapers, manuals, and others. This statement is also supported by 10 out 14 English teachers who claim that the texts used in the English textbook for students of VHSs should be dominantly authentic on the grounds that the authenticity of the texts facilitates students to easily understand the materials and to easily store them in long term memory. By contrast, 15 out 320 students propose to mix between authentic and non-authentic materials in the English textbook for students of VHSs as the combination of both authentic and non-authentic materials could enrich their knowledge of the materials. This statement is supported by 4 out of 14 English teachers as it is difficult to find authentic materials which are relevant to business management. To some extent, students tend to find difficulties to make sense of the authentic texts. Therefore, semi-authentic texts could be one of the alternatives to minimize the difficulties because of the complexity of the language use in authentic materials.

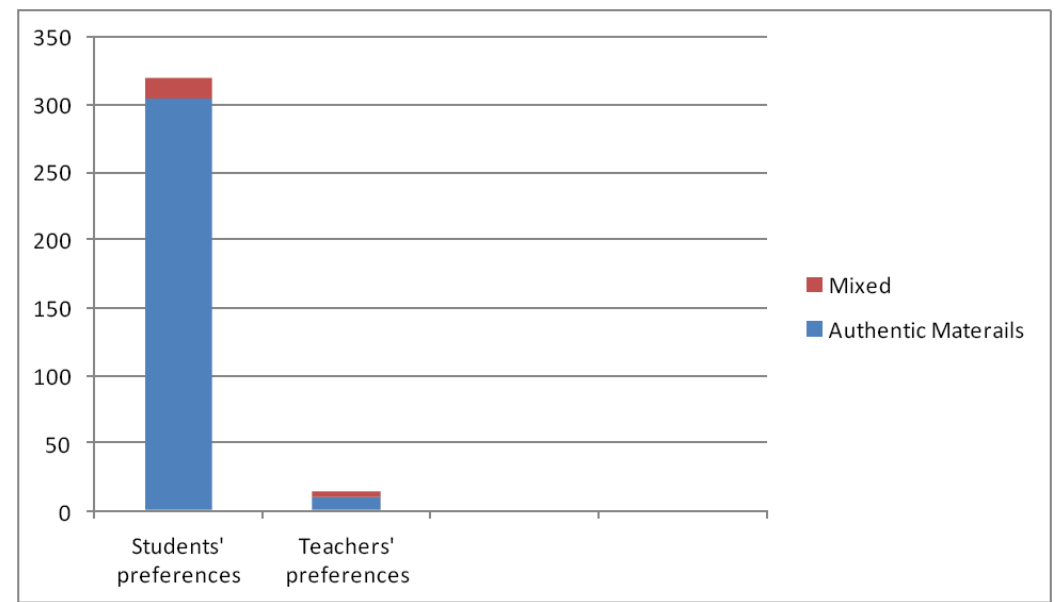

Figure 2. Students' and teachers' preferences on authentic and mixed materials in English textbook development 
In reference to the above findings, it is evident that the English textbook for students of VHSs and SHSs should be different as they have different orientation and expectation as previously mentioned. In addition, the way of developing English textbooks for students of VHSs should be based on English for specific purposes not general English. The development of HOTS as performed in every task should become the main concern on the grounds that it could enhance the critical thinking of students of VHSs which serves as the basis of establishing students' creativity and self-regulated learning on the part of students. This facilitates students of VHSs to acquire English as their target language on the grounds that they could make use of their long-term memory space to store the information gained through English language learning practices.

In relation to the development of HOTS in English textbook for students of VHSs, the following presents the example of tasks for reading presentation which can be used to develop the English textbooks. This sample attempts to accommodate needs assessment: learning and target needs as explored above. The first example is designed for students of VHSs who take agriculture as their study program. The second example is designed for students of VHSs who concentrate on business management.

Example 1: Study the following text and discuss the following comprehension questions with your partner.

Humans have struggled against the weeds since the beginning of agriculture. Marrying our gardens is one of the milder effects of weeds - any plants that thrive where they are unwanted. They clog waterways, destroy wildlife habitats, and impede farming. Their spread eliminates grazing areas and accounts for one-third of all crop loss. They compete for sunlight, nutrients, and water with useful plants.

The global need for weed control had been answered mainly by the chemical industry. Its herbicides are effective and sometimes necessary, but some pose serious problems, particularly if misused. Toxic compounds threaten animal and public health they accumulate in food plants, groundwater, and drinking water. They also harm workers who apply them.

In recent years, the chemical industry has introduced several herbicides that are most ecologically sound. Yet, new chemicals alone cannot solve the world's weed problems. Hence, scientists are exploring the innate weed-killing powers of living organisms, primarily insects and micro-organisms.

The biological agents now in use are environmentally benign and are harmless to humans. They can be chosen for their ability to attack selected targets and leave crops and other plants untouched. In contrast, some of the most effective chemicals kill virtually all the plants they came in contact with, sparing only those that are naturally resistant or have been genetically modified for resistance. Furthermore, a number of biological agents can be administered only once, after which no added applications are needed. Chemicals typically must be used in several times per growing season.

Comprehension Questions

(Rogers, 1999)

(1) Why does the writer select weeds as the topic of the text?

(2) How does the writer convince that weeds are disadvantageous?

(3) Why is the chemical industry used in the above text?

(4) How does the writer convince the readers about the importance of biological agents to eradicate the weeds?

(5) How are biological agents different from chemicals

(6) Analyze the relationships among the sentences in each paragraph.

With regard to the above texts and comprehension questions, students of VHSs are driven to make sense of text with the use of their higher order thinking skills which focus on evaluating the above text. This suggests that English teachers are encouraged to develop the tasks which drag students to use HOTS instead of LOTS as presented below. The following task also deals with HOTS development through reading practices.

Example 2: Study the following text and discuss the following comprehension questions with your partner. 
We live in the age of technology. Everyday, new technology appears, ranging from mini-CDs that contain entire encyclopedias to giant space telescopes that can send photographs of distant stars back to Earth. Of all the new technological wonders, personal computers have probably had the greatest influence on the daily lives of average people. Through computers, we can now talk to people in any country, research any topic, work, shop, bank, and entertain ourselves. Personal computers have especially revolutionized communication and business practices in the past twenty years.

Perhaps the most important effect of personal computers has been to expand our ability to communicate with the outside world. A lonely invalid in Minnesota can talk with a similarly house-bound person in Mississippi .Schoolchildren in Mahattan can talk via computer to school children in Moscow. A high school student can obtain statistics for history paper from a library in London. A single computer user can send an email message to millions of people all over the world with one keystroke. Computer users can get an online "chat room" to discuss their interests and problems with other who have similar interests and problems. For example, a person whose hobby is collecting antique guns can share information with other gun collectors via computer. A person who is planning a vacation and wants to know the names of the best beaches in Hawai can ask others who have already been there for suggestions. People even start online romances in chat rooms! The possibilities of computerized communication are indeed unlimited.

Besides, improving communication, personal computers have made it possible to do business for home. You can take care of personal business. For example, you can buy airlines tickets, send flowers for a friend, pay your bills, buy and sell stocks, and even pay your taxes from you home computer at any time of the day or night. This is a great convenience for people who are busy during the day and for physically disabled people who find it hard to leave their homes. Moreover, telecommunicating-working at home instead of going to the office- has become a choice for thousands of business people. Suzzane Carrerio, a financial manager for a large company in downtown Mahattan, has telecommuted from her home in New Jersey for the past two years. She goes to her office only once a week. Four days a week, she works at homes and communicates with her staff by computer. She says, I am much more productive when I work at home because there are no interruptions. I also don't have to spend three hours travelling to and from the office everyday. I save my time and I save my company money for telecommuting".

In brief, the computer age has arrived, and it is changing our lives. Computers have made communicating and doing business faster and more convenient, and they have greatly increased our access to information. Just as the invention of automobiles had an unplanned consequence-the growth of suburbsso will the invention of personal computers. We will have to wait and see what these unintentional consequences will be.

Adapted from http://otraotradition.blogspot.ru/2010/08/computer--revolution.htm

\section{Comprehension Questions}

(1) What points are offered by the writer through the above text?

(2) Why does the writer offer personal computers as the topic of the text?

(3) How does the writer convince the readers that personal computers are beneficial?

(4) What parties could get benefits from personal computers?

(5) Find the main idea of each paragraph and give reasons for each?

(6) Analyze the consequences of the development of technology.

In reference to the comprehension questions, students are challenged to actively seek out the reasons for their answers with the application of HOTS by analyzing the text comprehensively. In order words, students are triggered to apply their thinking skills beyond memorization and understanding. This assists students to enhance their critical thinking skills.

\section{CONCLUSION}

In reference to the above findings, it is evident that English textbooks should be developed under the issue of HOTS enhancement on the grounds that HOTS could facilitate students of VHSs to maximally acquire the target language (English). This relies on the theory that the development of HOTS as manifested in the tasks of the English textbooks trigger students to establish their creativity and self-regulated learning which are of great importance for acquiring the target language. Added to this, the development of HOTS through English textbooks could facilitate students to enhance their critical thinking skills which initiate the success for English language attainment. This clearly implies that English language teachers should be concerned about selecting appropriate and challenging English textbooks which could establish students' critical thinking skills which are of great importance for acquiring the target language.

\section{REFERENCES}

[1] Anderson, L.W, J. \& Krathwohl, D. R. (2001). A taxonomy for learning, teaching, and assessing: A revision of Bloom's taxonomy of educational objectives. New York: Addison Wesley Longman.

[2] Bell, J. \& Gower, R. (1998). Writing course materials for the world: A great compromise. In B. Tomlinson (ed.). Material development in language teaching (pp. 116-129). Cambridge: Cambridge University Press.

[3] Beyer, B. K. (1988). Developing a thinking skill program. Boston, M.A: Allyn and Bacon, Inc.

[4] Beyer, B. K. (1995). Critical thinking. Bloomington, IN: Phi Delta Kappa. Educational Foundation.

[5] Beyer, B.K. (1997). Improving students' thinking: A comprehensive approach. Boston, M.A: Allyn and Bacon, Inc. 
[6] Bloom's. (1956). Revised Taxonomy by Michael Pohl for the QSITE Higher order Thinking Skills Online Course 2000 http://rite.ed.qut.edu.au/oz-teachernet/training/bloom.html. (retrieved on 30 July 2016).

[7] Byrd, P. (2001). Textbooks: Evaluation for selection and analysis for implementation. In M. Celce-Murcia. Teaching English as a second or foreign language. (3rd Ed.) (pp. 415-427). US: Heinle \& Heinle, Thomson Learning Inc.

[8] Carrol, T. M. (1989). Critical thinking: Promoting it in the classroom. ERICDigest [On-line]. Available: http://ericae2.educ.cua.edu/edo/ed306554.htm (retrieved on 15 May 2016).

[9] Chambliss, J.M. \& Calfee, C.R. (1998). Textbooks for learning: Nurturing children's minds. Oxford: Blackwell Publishers.

[10] Chamot, A. (1995). Creating a community of thinkers in the ESL/EFL classroom. TESOL Matters, 5(5), 1-16.

[11] Chapple, L., \& Curtis, A. (2000). Content-based instruction in Hong Kong: Student responses to film. System, 28, 419-433.

[12] Connolly, M. (2000). What we think we know about critical thinking. CELE Journal, 8, Retrieved April 20, 2003, from http://www. asia-u.ac.jp/english/cele/articles/Connolly_Critical-Thinking.htm (retrieved on 15 July 2016).

[13] Cotton, K. (1997). Teaching thinking skills: School Improvement research series [On-line]. Available: http://www.nwrel.org/scpd/sirs/6/cu11.html (retrieved on 15 July 2016).

[14] Cramp, W. et al. (1988). Teaching HOTS in the middle and high school: A district level initiative in developing higher order thinking skills. ROEPER Review 10 (4), 205-211.

[15] Cunningsworth, A., \& Kusel, P. (1991). Evaluating teachers" guides. ELT Journal 45(2), 128-139.

[16] Cunningsworth, A. (1995). Choosing your course book. Oxford: Heinemann.

[17] Davidson, B. (1994). Critical thinking: A perspective and prescriptions for language teachers. The Language Teacher 18(4), 20-26.

[18] Davidson, B. (1995). Critical thinking education faces the challenge of Japan. Inquiry: Critical Thinking across the Disciplines 14(3), 41-53.

[19] Davidson, B. (1998). A case for critical thinking in the English language classroom. TESOL Quarterly 32, 119-123.

[20] Davidson, B., \& Dunham, R. (1997). Assessing EFL student progress in critical thinking with the Ennis-Weir critical thinking essay test. JALT Journal 19 (1), 43-57.

[21] Ennis, R. (1987). A taxonomy of critical thinking dispositions and abilities. In J. Baron and R. Sternberg, Teaching Thinking Skills, New York, W.H. Freeman, 9-26

[22] Ezici, I. (2006). Evaluation of the EFL Textbook "New Bridge to Success 3" from the Perspective of Students and Teachers. Unpublished Master's Thesis.

[23] Facione, P. A. (1998). Critical Thinking: What it is and Why it Counts. California: California Academic Press.

[24] Harmer, J. (1991). The practice of English language teaching. Harlow, Essex: Longman.

[25] Hedge, T. (2008). Teaching and learning in the language classroom. New York: Oxford University Press.

[26] http://otraotradition.blogspot.ru/2010/08/computer--revolution.htm (retrieved on 20 August 2016).

[27] Huberty, C. J., \& Davis, E. J. (1998). Evaluation of a state critical thinking skills training program. Studies in Educational Evaluation 24(1), 45-69.

[28] Hutchinson, T. \& Torres, E. (1994). The Textbook as Agent of Change. In ELT Journal48 (4), 315-328.

[29] Iqbal, J. (2013). A review of English textbook at secondary level in the province of Khyber Pakhtunkhwa, Pakistan. Research Journal of Educational Sciences 1(3), 1-5.

[30] Jacobs, S. S. (1994). Technical characteristics and some correlates of the California critical thinking skills test, forms a and b. ERIC Document Reproduction Service No. ED 373631

[31] King, FJ, Goodson, L, \& Rohani, F. (2007). Higher order thinking skills. The center for advancement of learning and assessment .www.cala.fsu.edu (retrieved on 25 July 2016).

[32] Kitao, K. \& Kitao, K, S. (1997). Selecting and developing teaching/learning materials. The Internet TESL Journal, Vol. IV, No: 4. Available on http://iteslj.org/Articles/Kitao-Materials.html (retrieved on 25 July 2016).

[33] Liaw, Meei-Ling. (2007). Content-based reading and writing for critical thinking skills in an EFL Context. English Teaching \& Learning 31(2) (Summer 2007), 45-87.

[34] Mukundan, J. \& Ahour, T. (2010). A review of textbook evaluation checklists across four decades (1970-2008). In Tomlinson, B., Masuhara, H. (Eds.). Research for materials development in language learning: Evidence for best practice (pp. 336-352). London: Continuum.

[35] Margana. (2015). Voices of English teachers and students on blended culture as a model of English language teaching and learning at vocational high schools in Yogyakarta. Mediterranean Journal of Social Sciences 7 (3), 459-466.

[36] Mayfield, M. (2001). Thinking for yourself: Developing critical thinking skills through reading and writing (5th ed.). New York: Thomas Learning.

[37] Nejmeh, A.S. (2011). Integrating higher order thinking skills (HOTS) on the tenth graders to improve learners' achievements in reading comprehension. Unpublished thesis. Al Najah National University, Palestine.

[38] Putcha, H. (2012). Developing thinking skills in young learners' classroom. Cambridge: Cambridge University Press

[39] Renner, C. E. (1996). Enrich learners' language production through content-based instruction. Paper presented at a National Conference on Lingua e Nuova Didattica, Modena, Italy. ERIC Document Reproduction Service No. ED 411694.

[40] Richards, J.C. (2001). Curriculum development in language teaching. Cambridge: Cambridge University Press.

[41] Richards J.C., \& Schmdit, R. (2010). Longman dictionary of language teaching and applied linguistics. (4th ed). Harlow: Pearson Education Ltd.

[42] Rogers, B. (1999). Peterson's TOEFL Success. New Jersey: Peterson's Education Center.

[43] Sheldon, L. E. (1988). Evaluating ELT textbooks and materials. ELT Journal 42(4), 237-246.

[44] Tarvin, W., \& Al-Arishi, A. (1991). Rethinking communicative language teaching: Reflection and the EFL classroom. TESOL Quarterly 25(1), 9-27.

[45] Tsou, W. (2009). Needs-based curriculum development: A case study of NCKU's ESP program, Taiwan International ESP Journal, Vol. 1: 1, 77-95. [Online] available: http://www.tespa.org.tw/papers/01/07-Needs-basedcurriculumdevelopmentAcasestudyofNC KUsESPprogram_WenliTsou.PDF (retrieved on 25 July 2016). 
[46] Ur, P. (1996). A course in language teaching: Practice and theory. Cambridge: Cambridge University Press.

[47] Widyati, U., Furaidah, \& Rohmah, Z. (2014). Bahasa Inggris untuk SMA/MA/SMK/MAK Kelas X Semester 1. Jakarta: Kementerian Pendidikan dan Kebudayaan.

[48] Young, A. C. (1997). Higher-order learning and thinking: What is it and how is it taught? Educational Technology 37, 38-41.

[49] Zabawa, J. (2001). Criteria for FCE textbook evaluation: an attempt at questionnaire formulation: http://www.univ.rzeszow.pl/fil_ang/wsar2/sar_v2_17.pdf (retrieved on 25 July 2016).

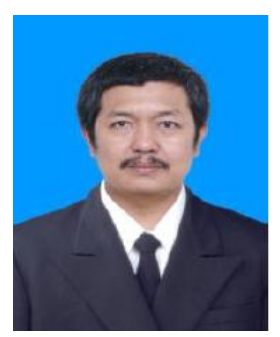

Margana is one of the staff members of English Education Department, Faculty of Languages and Arts, Yogyakarta State University, Indonesia. He was born on April 7, 1968. He got a Master of Humanity (M.Hum.) in Linguistics from Gajah Mada University in 1999. He also obtained a Master of Arts (M.A.) in Applied Linguistics from University of Newcastle in 2005. He gained a Doctoral degree from University of Gadjah Mada majoring in Linguistics in 2012. His interests include bilingualism, code-switching, discourse analysis, and second language acquisition.

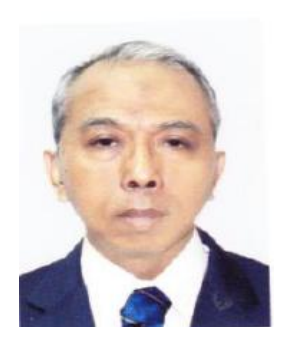

Agus Widyantoro is one of the staff members of English Education Department, Faculty of Languages and Arts, Yogyakarta State University, Indonesia. He was born on 8 March 1960. He got a Master of Education from IKIP Jakarta. He obtained his doctorate degree from Yogyakarta State University, Indonesia. He has been teaching in the English Education Department, Faculty of Languages and Arts, Yogyakarta State University for more than 30 years. His interests include English language teaching. 